\title{
When Collaborative Development Meets NeW Public GovernanCE: THE CASE OF ETORKIZUNA ERAIKIZ TERRITORIAL DEVELOPMENT LAB IN GIPUZKOA

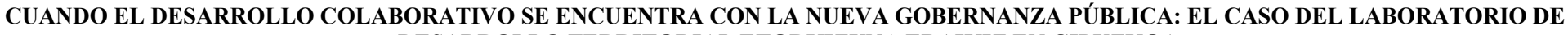 DESARROLLO TERRITORIAL ETORKIZUNA ERAIKIZ EN GIPUZKOA
}

\author{
Ainhoa Arrona $^{1 *}$, Miren Estensoro ${ }^{1}$, Miren Larrea ${ }^{1}$, and Eduardo Sisti ${ }^{1}$ \\ Orkestra-Basque Institute of Competitiveness, University of Deusto, Spain ${ }^{1}$ \\ *corresponding author: ainhoa.arrona@orkestra.deusto.es
}

\begin{abstract}
Etorkizuna Eraikiz Territorial Development Lab (TDLab) is a long-term action research process that has produced a change towards more horizontal forms of territorial development and policymaking governance in Gipuzkoa. The article analyses this experience to reflect on the role of public organisations in steering cooperative forms of territorial development. Specifically, the article suggests that cooperative forms of territorial development may need network-based public organisations; and it shows that TDLab has fostered and embodied practices framed under New Public Governance (NPG), a network-based public administration paradigm. By reflecting on how such practices were fostered in TDLab, the article also suggests a potential complementarity between New Public Governance and action research for territorial development, the research approach and change strategy developed in TDLab, as a means of better contributing to network-based public organisations.
\end{abstract}

Key words: territorial development, New Public Governance, action research, governance

Resumen: El Laboratorio de Desarrollo Territorial de Etorkizuna Eraikiz (TDLab) es un proceso de investigación acción a largo plazo que ha producido un cambio hacia formas más horizontales de desarrollo territorial y gobierno de las políticas en Gipuzkoa. El artículo analiza esta experiencia para reflexionar sobre el papel de las organizaciones públicas en la facilitación de formas cooperativas de desarrollo territorial. Específicamente, el artículo sugiere que las formas cooperativas de desarrollo territorial pueden necesitar organizaciones públicas en red; y muestra que TDLab ha fomentado y encarnado las prácticas enmarcadas en la Nueva Gobernanza Pública, un paradigma de administración pública basado en el concepto de red. Al reflexionar sobre cómo se fomentaron tales prácticas en TDLab, el artículo también sugiere una posible complementariedad entre la Nueva Gobernanza Pública y la investigación acción para el desarrollo territorial, el enfoque de investigación y la estrategia de cambio desarrollada en TDLab, como un medio para contribuir mejor a la red de organizaciones públicas.

Key words: desarrollo territorial, Nueva Gobernanza Pública, investigación acción, gobernanza

\section{Introduction}

Since political science underwent the so-called shift from government to governance more than two decades ago, the idea that horizontal and cooperative collective problem-solving strategies should replace traditional top-down governing approaches has pervaded many academic fields and practices (Klijn \& Koppenjan, 2016; Pollitt \& Hupe, 2011). This governance discourse has also permeated territorial development theory and practice, where a range of different reasons support the concept that governing modes moving away from control-based forms of steering are key for place-based territorial development (Barca, McCann, \& Rodríguez-Pose, 2012; Karlsen \& Larrea, 2014; Laranja, 2012; OECD, 2010; Pike, Rodríguez-Pose, \& Tomaney, 2007).

In this article, we reflect on the implications that such cooperative forms of steering territorial development have for public organisations. Our
European Public \& Social Innovation Review

Volume 3, Issue 1, 2018 ISSN 2529-9824

Creative Commons 4.0. International

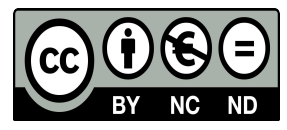


main argument is that territorial development needs collaboration-based public organisations that are grounded in the practices of the New Public Governance (NPG) public administration paradigm. NPG rests on the idea that intra- and inter-organizational collaboration and stakeholder empowerment will provide more efficient and democratic public action (Osborne, 2006; Torfing \& Triantafillou, 2013; Waldorff, Ebbesen, \& Kristensen, 2014). This argument is explored by revisiting the case of Etorkizuna Eraikiz Territorial Development Lab (TDLab), the action research lab for territorial development, and the efficiency of policies in Gipuzkoa (Basque Country).

Moreover, the analysis of the case provides valuable insights towards understanding how change has been fostered through action research for territorial development (ARTD), the work method and change strategy on which TDLab has been based.

The article is structured as follows. The next section reviews the rationale that frames the need for cooperative forms of governance in territorial development and its link to New Public Governance in order to extract key guidelines to analyse and discuss the case. Section 3 then presents the case and its work method, ARTD. Section 4 discusses the case in relation to the links of TDLab and ARTD with NPG. The article concludes with a brief summary.

\section{New Public Governance for territorial development}

\subsection{The need for networked modes of steering for territorial development}

Currently, a range of different logics, rationales and lines of argument call for interactive and networked forms of governance in territorial development (Barca et al., 2012; Karlsen \& Larrea, 2014; Laranja, 2012; OECD, 2010; Pike et al., 2007). One of the strongest and - in our view most fundamental arguments for this need derives from the acknowledgement of the contested nature of development. Although sometimes presented as a rational and value-free process, territorial development is a highly political activity. Regional development takes place in complex contexts in which diverse and conflicting visions about the nature and the goals of development exist
(Karlsen, 2010; Karlsen \& Larrea, 2014; Pike et al., 2007; Sotarauta, 2005). Thus, development is strongly normative: what constitutes development is dependent on the contexts and the notions that people and groups have about it and what they judge to be priorities (Bristow, 2010; Pike et al., 2007). In that sense, "achieving answers to the question of 'what kind of local and regional development and for whom?' (...) involves compromise, conflict and struggle between sometimes opposing priorities" (Pike et al., 2007: 1266). In effect, territorial development can ultimately be thought as the "struggle between visions, development ideas and interests" (Sotarauta, 2009: 903).

Moreover, regional economies are multiscalar spaces where not only public and private actors but also different multi-level administrative levels interact and where a high density of institutions with diverging interests are involved in policymaking and steering regional development (Karlsen, 2010). The multiple agents, organisations and practices within territories make certain that the power, knowledge and resources for territorial development are distributed and dispersed throughout this myriad of actors who have to continuously dialogue and negotiate (Karlsen \& Larrea, 2014; Sotarauta, 2005). Consequently, in order to develop territorial strategies and bring about collective action, it is necessary to establish governance mechanisms that allow dialogue, communication and cooperation among the different actors involved in territorial development (Alburquerque, Costamagna, \& Ferraro, 2008; Karlsen \& Larrea, 2014; Pike et al., 2007).

\subsection{The need for network-based public organisations}

Cooperative forms of steering territorial development have undeniable implications for the role of governments and public organisations. Leadership and facilitation of territorial development is not exclusive of governments, and previous studies have shown that place-based leadership and facilitation is an interdependent, non-linear and dispersed phenomenon among many territorial actors (Beer \& Clower, 2014; Costamagna \& Larrea, 2017; Sotarauta, 2005). However, governments and public organizations still have a key role in the alignment and 
facilitation of the collective effort. But what is that role, and how is it enacted?

We can learn from recent developments in public administration and governance research. A strong line in this field claims that public organisations should be based on networked forms of governing and collaboration in order to meet current society's needs. It is argued that public administration should transit towards what has been labelled as New Public Governance. A network-based administration paradigm, NPG is based on the idea that intra- and inter-organizational collaboration and stakeholder empowerment will provide more efficient and democratic public services and actions (Osborne, 2006; Torfing \& Triantafillou, 2013; Waldorff et al., 2014).

Governance scholars claim that traditional hierarchical, rule-based and highly specialized and compartmentalised administrations lack both the flexibility to adapt to emergent changes and the holistic approach to problems that are affected by and thus can be tackled from several fields and departments. Equally, the managerialism logic of New Public Management based on rationalisation, atomisation of activities and private-sector logic cannot be valid to steer a public action and territorial development process in pluralist contexts that are by nature political. In contrast, NPG rests on the idea that the current complex and wicked nature of policy problems needs to include diverging visions and knowledges to frame and solve problems; that policy goals are negotiated in interactive processes and central controls have limits; and thus, public problem-solving should be fostered though networked forms of governance that promote a relational public action that no longer divides the politics and administration tasks and design and implementation of public policy and service delivery (Osborne, 2006; Torfing \& Triantafillou, 2016). Such type of public administration also changes the traditional roles of policy actors and citizens in public action in regards to previous paradigms. Political leaders are to be more actively involved in defining problems and orchestrating interests, and public officials become the leaders of collaboration-based processes both internally and with external actors. Thus, a networked governance approach that features trust and relational contracts as key governance mechanisms, and an administration that works to enhance the collective capacity for public problem-solving and constructing long-term inter-organizational relationships, seems to better fit today's world (Osborne, 2006).

\subsection{New Public Governance meets territorial development}

Making a parallel case between the claims that argue for network-based public organisations and the governance requirements of territorial development, it is reasonable to suggest that cooperative and horizontal governance arrangements for territorial development and policymaking require public organisations organized and based on collaboration. Undeniably, real governance is not determined by these paradigms, which are just analytical constructs that try to characterize different rationales of public action (Bevir, 2013; Torfing \& Triantafillou, 2016; Waldorff et al., 2014). However, a public sector that acknowledges the complexity and pluralist character of the reality in which it is embedded, seeks to foster public value through empowering stakeholders and does so based on collaboration with external actors is much closer in our view to the needs of steering territorial development as a collective multi-agent, multi-knowledge and contested process. Next, we explore this idea in the case.

\section{Etorkizuna Eraikiz Territorial Development Lab}

Launched by the provincial government of Gipuzkoa (the Council) in 2009, TDLab is an action research process in which three of the article authors currently participate and the fourth author participated until 2016. The relationship between the research team and the project has developed since 2009 through annual research contracts, creating a fairly stable framework for the development of a long-term research process. The case will be analysed based on project documents (meeting minutes and project dissemination documents) and author reflections. Before describing and analysing the case through the NPG prism, next we present the specific work method on which TDLab has been based. 


\subsection{The work method: Action research for territorial development}

TDLab is based on action research for territorial development (ARTD). Although action research comprises several approaches, overall it is a research approach with an agenda of social change that (1) is based on specific contexts and tries to focus on real problems, (2) gathers researchers and actors in joint knowledge co-generation processes, (3) recognizes that different knowledge and experiences contribute to the process and (4) understands that co-generated knowledge leads to social action (Greenwood \& Levin, 2007). ARTD is a specific action research approach and strategy for generating change in territorial development, developed in the context of Orkestra - Basque Institute of Competitiveness in the intersection of the fields of action research and territorial development. TDLab has been one of the experiences that has most contributed to its development.

The most comprehensive framework of ARTD is the co-generative framework developed by Karlsen and Larrea (2014). Figure 1 describes the cogenerative cyclical process that takes place between researchers and policymakers. The process starts by practitioners and researchers agreeing on a problem they both "own"; that is, a problem they want to contribute to solving (e.g., changing governance, promoting innovation in companies). Reflection and action cycles in which researchers play a strong facilitator role enable the generation of collective knowing, which researchers and practitioners will later take to their own professional spheres, eventually bringing new problems that need to be solved in the agora.

Figure 1. Cogenerative framework of ARTD

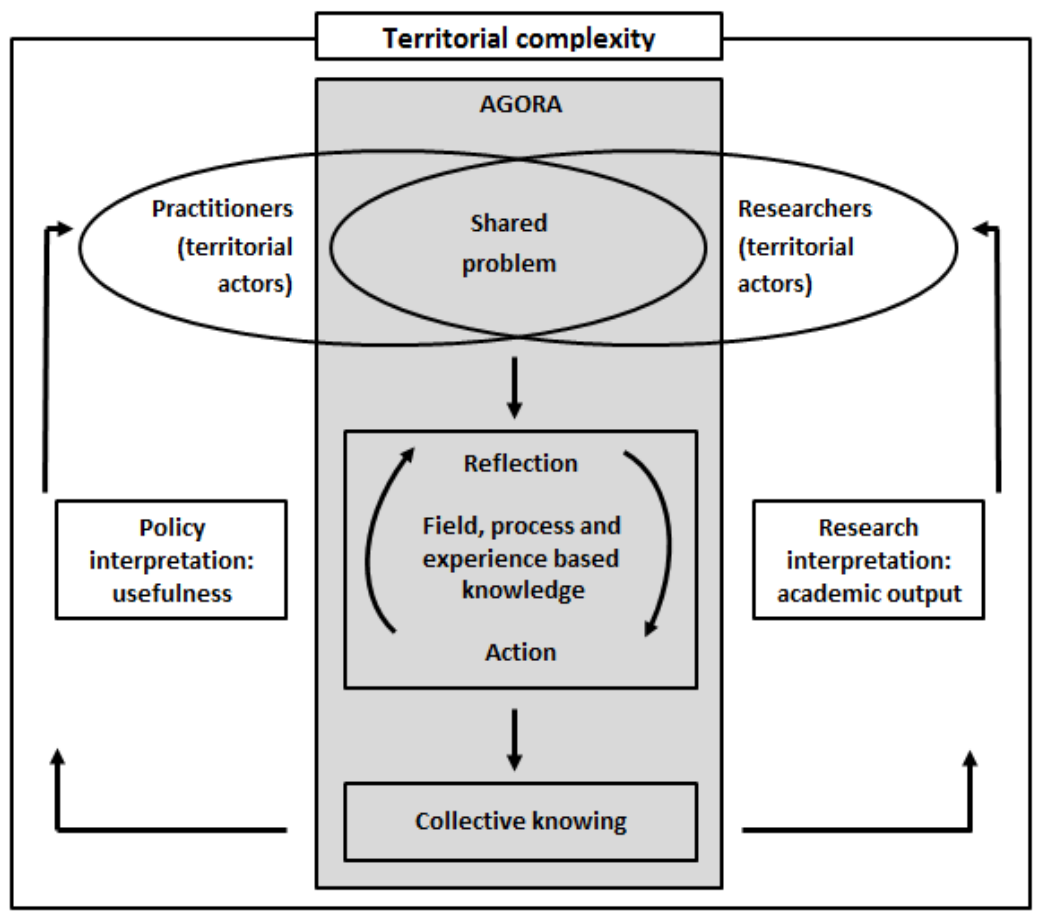

Source: Karlsen and Larrea (2014: 100). 


\subsection{Timeline and significant events of the case}

As mentioned, TDLab is a Council-launched process focused on developing new patterns of relationships with territorial actors in order to generate more democratic and efficient policy processes and policies for territorial development. In administrative and political terms, the Basque Country has a regional government, three provincial governments and municipal councils. In the $1980 \mathrm{~s}$, most of the municipalities created county-level economic development agencies (county agencies). These agencies (11 in Gipuzkoa) are inter-municipal joint authorities through which local economic promotion is made (Estensoro, 2012). Prior to TDLab, the Council and the 11 agencies defined and developed their own strategies, and coordination among them was through one-on-one informal communication. As a result of the action research process, new formal governance mechanisms were created by developing collaborative spaces between the Council and the county agencies in order to foster more aligned territorial development processes and involve counties in the definition of territoriallevel development policies.

TDLab has been presented in project dissemination documents consisting of different stages, determined among others, by different ruling governments that have led the process. In the following sections, we analyse each stage, sharing the main features of NPG that can be found in TDLab. We illustrate and later discuss the following NPG features (based on Hartley, 2005; Klijn \& Koppenjan, 2016; Waldorf et al., 2014; and Torfing \& Triantafillou, 2016):

a) Politicians participate in / facilitate negotiation

b) Political leaders orchestrate interests; they lead the definition of problems and the development of solutions

c) The inclusion of different knowledge and joint problem-solving as a strategy to deal with complex problems

d) Public administration contributes to improving stakeholders' problem-solving capacity

e) Public officials lead intra- and interorganizational coordination.

Most of these features can be found at different periods, spaces and practices of the project. However, we have selected the main practices that embody such NPG features in each period. From this view, TDLab can be synthetized into the following timeline:

Figure 2. Timeline of the case

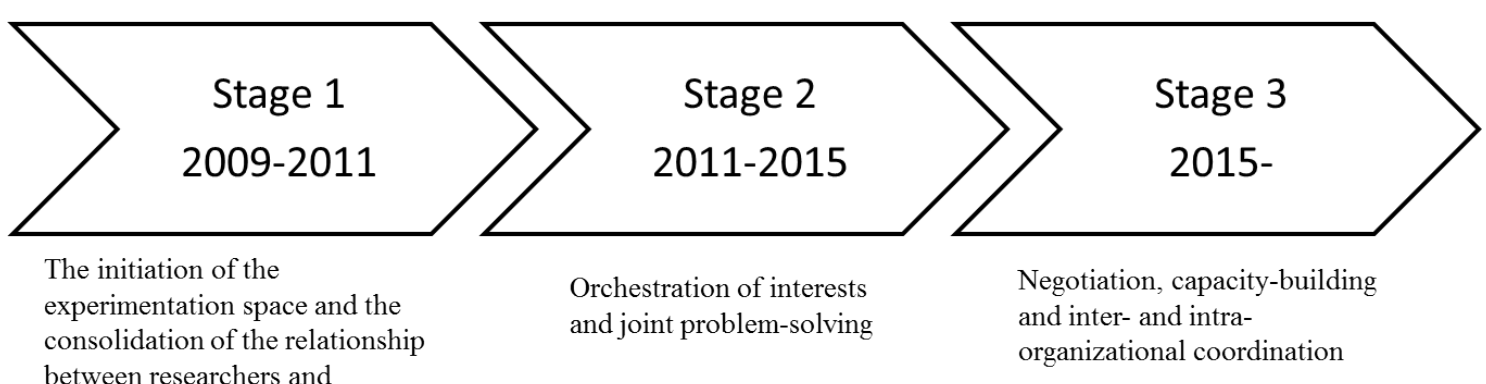

organizational coordination

policymakers

Source: Authors 
2.2.1. STAGE 1 (2009-2011): The initiation of the experimentation space and the consolidation of the relationship between researchers and policymakers

The project (at the time named Gipuzkoa Sarean [Networking Gipuzkoa]) was launched by the Council with the goal of fostering the competitiveness and well-being of Gipuzkoa through strengthening social capital. The project was conceived as having both research and action dimmensions, and was thus viewed as a collaboration project between researchers and policymakers. The Council established a team to run the project led by representatives from the Council President's cabinet and from the city council of the capital of Gipuzkoa, researchers from three different universities (Orkestra - the institution the authors belong to - among them) and communication advisers. In its first year, several research activities and workshops with territorial actors were developed to define and implement projects to foster social capital. Nevertheless, process-wise and in order to understand TDLab in the long term, the first year and a half were mainly relevant because they enabled the generation of a working dynamic between researchers and policymakers that would be decisive for the continuation and the development of the project from that point on (see Karlsen \& Larrea, 2014, and Orkestra \& Gipuzkoako Foru Aldundia, 2015). As stated by the main political representative of the project at the time:

the work developed until now has served specially for: achieving the coordination of a working group and learn to work together, which at the same time contributes to know how to experiment with other working groups (...)

(Excerpt from a Steering group meeting, 22 March 2011)

\subsubsection{STAGE 2 (2011-2015): Orchestration of interests and joint problem-solving}

In May 2011, local elections brought a new party to the government of the Council. Discussion between researchers and policymakers led to the redefinition of the overall goal: "to propose a new socio economic regional development model for Gipuzkoa, based on participation and with the counties at its heart." The new government had an interest in developing a holistic approach to development that would go beyond economic promotion and in increasing the relevance of the local level and counties.

Looking back, we now think that one of the ideas shared by a government member in a 2012 researcher-developed workshop perfectly illustrates the work initiated in this period and followed since then in TDLab:

[in this territorial development approach] The political level assumes two basic aspects: (1) Make a clear decision (2) Assumes an "orchestra conductor" function of the group of actors

(Transcribed from a Council policymaker's post-it note shared during group discussion)

Indeed, the government made a decision to define a territorial development proposal and initiate dialogue with territorial actors to discuss this proposal and to work together on territorial development strategies and policies. The rationale of the proposal was a combination of political goals and research-derived frames. The Council wanted to develop a holistic view of territorial development through a participatory approach that would lead to more demoratic practices, focusing on counties in a way that local actors could influence Council policies. The proposal was also strongly influenced by research frameworks provided by ARTD that emphasized the complexity of territorial contexts and problems and the consequent need to base territorial development in participation, the creation of shared vision and trust relationships and the development of territorial strategies based on learning, negotiation and collaboration. This proposal was the first step towards discussion with territorial actors and working with them:

The presented contents do not constitute a close model. This would be contradictory with the methodology chosen for the process. They constitute concepts and frameworks for reflection and analysis that allow opening a debate about development in the territory. Only 
through dialogue with territorial actors on this basis can [we] make advances towards the implementation of a new model of territorial development.

(Excerpt from "A proposal for a new territorial development approach for Gipuzkoa," 2012)

Several dialogue spaces were created in 2013 with the purpose of introducing changes in governance and policies. Since the counties were the main focus of the project the core governance spaces were constituted by agency and Council representatives. The first space to be created, which remains as the main political collaborative space, was the Inter County Table (ICT).

The ICT is a dialogue and negotiation space for Council policymakers and county agency representatives. Besides agency directors (technical staff), it was decided to invite political representatives (mayors of municipalities) into these dialogues. If territorial development strategies were to be aligned and defined, and territorial development is not a technocratic but rather a political phenomena, it was relevant to include the political representatives in such definitions. This constituted a significant innovation, since before TDLab the relationship between agencies and Council policymakers was mainly based on specific projects and programmes at the technical level; that is, between Council civil servants and agency directors.

The ICT aimed to collectively define some territorial challenges that the actors would consider relevant. But it also created specific groups to work on joint problem-solving of specific economic development-related issues. The groups would not only gather members of the ICT but also other departments of the Council and even of the Basque government whenever the issues were affected by these departments and institutions. New programs (such as a program to dynamise local employment promotion or to analyse energy value chain and mapping of companies for the sector) and an agreement to foster internationalisation resulted from the work in these groups.

Another relevant collaborative space created in this period is the facilitators action research process (FARP), a space facilitated by researchers that brought together county agency technical staff and Council policymakers to strengthen territorial development facilitation capacities. If participatory ways of steering territorial development were to be promoted, those who in their everyday work also enact such processes in the counties needed to be part of the process. Moreover, this staff is mainly those who manage collaboration networks and interact on a daily basis with companies and other actors in their counties, so strengthening their capacities to manage those processes was seen as necessary. We will delve into these facilitation capacities in the next section, since politicians were involved more deeply in this endeavour in the following period.

\subsubsection{STAGE 3 (2015-): Negotiation, capacity-building and inter- and intra- organizational cooordination}

In May 2015, local elections again brought a new government (with a new party) to the Council and to many of the municipalities. In the initial months, the Council adapted TDLab to its government programme, which would now put a special focus on the efficiency of processes and programs to reach small companies. In order to achieve this, the action research methodology would be maintained.

The main milestone of this period was the formalization of a new mode of governance established between the Council and the county agencies in June 2017 that would be based on the project's two core spaces: the ICT and the FARP. This meant that the spaces for action research that had been created in the previous term became institutionalized. In a nutshell, the ICT consolidated as the space in which representatives from the Council and the agencies decided every June/July about what their collaboration will focus on in the upcoming year. Following these decisions, budgets and programs are designed, which are launched after January. In order to develop the programs in collaboration, the FARP was institutionalized too.

To illustrate the role of politicians in the negotiation processes, we now focus on the period before the June 2017 signing of the formal agreement. The negotiation process was agreed to in a workshop held May 27, 2016. The challenge of the process, as included in the meeting minutes, was to "decide in a coordinated way which is the role [of each of the participants] in economic development." The preliminary stage of the process consisted of three bimonthly workshops in which researchers helped policymakers to get to 
know one another's positions and made an exercise of empathy in order to build a shared vision. As the following excerpt illustrates, several open issues needed first to be framed as common interests:

At this moment there are many open questions: in which direction has the territory need to go? How do we have to work the different actors? How do we have to promote new collaborations? (...) the results of this process will be very valuable in that sense.

(Statement from the main Council representative for TDLab, ICT meeting minutes, 4 July 2016)

Researchers developed several documents and analyses to help this process. These were then shared and discussed together in two workshops held in July and September 2016. Another three bimonthly workshops were designed as the negotiation process. In the words of one of the county politicians in the last meeting before the signing of the agreement:

This agreement protects a territorial vision. In Arrasate [the first meeting of this process] it looked like each county worked on their own and that we each tried to find our own interest. (...) The process has been bottom up. It is something to highlight... the methodology: working collaboratively

(Excerpt from meeting notes of a Orkestra team member, ICT meeting, 23 February 2017)

Once the new governance was institutionalized, one of the challenges that emerged from the process and was detected in the dialogue process between policymakers and researchers was the need for policymakers in the Council and in the agencies to facilitate the new governance.

Although the need for facilitation capacities and building such capacities had already started in the FARP, in order to reinforce this, a virtual capability-building process was agreed on between policymakers and researchers. Once the virtual space was ready, politicians in the project were actively inviting other policymakers to participate. We don't go deep into this process here because an article in this special issue (see Canto, Costamagna, Eizagirre and Larrea, 2018) presents that specific project, but we underline the relevance of the role of politicians in the capability-development process.

Finally, we illustrate the role of policymakers in the process of the construction of inter- and intra-organizational coordination. The ICT is a clear example of inter-organizational coordination. Likewise, we highlight here that a significant effort has been made inside the Council to integrate different directorates into the process. At the beginning of Stage 3, in 2015, only two policymakers from the Council's President Cabinet participated in the meetings with researchers every Wednesday. In 15 February 2017, the members of the Economic Promotion department started to participate every second Wednesday. In 20 September 2017, the representatives of the Social Services Department also integrated into the process. Whereas initially all meetings were facilitated by researchers in 17 January 2018, policymakers from the President's Cabinet started to facilitate the meetings with other directorates, thus transforming an action research space into an intra-organizational coordination space in the Council. The following excerpt from the TDLab leader illustrates the relevance of this new intracoordination dynamic:

\section{This space shared between the department and the Cabinet has developed, in turn, a new way of working in the Provincial Council. It is not usually easy to overcome the boundaries between departments, but to elaborate the new proposal, it has been essential to do so. Being that achievement also a result of Gipuzkoa Sarean, I considered that it was worth sharing with all of you.}

(Statement from the Council representative for TDLab, TDLab Bulletin \#16, November-December 2016)

\section{Discussion of the case}

Throughout the case, we have described practices in TDLab that, in our view, are very much aligned with practices that NPG scholars claim for public organisations. We have synthesised such practices in Table 1. 
Table 1. Alignment of NPG practices with TDLab practices

\begin{tabular}{|c|c|}
\hline NPG strategies, practices and roles & Practices in TDLab \\
\hline $\begin{array}{l}\text { Politicians participate in/ facilitate policy goals } \\
\text { negotiation }\end{array}$ & $\begin{array}{l}\text { - Active participation of Council and county } \\
\text { politicians in ARTD as a strategy to negotiate } \\
\text { territorial development strategies and the roles of } \\
\text { each within them }\end{array}$ \\
\hline $\begin{array}{l}\text { Politicians orchestrate interests; they lead the } \\
\text { definition of problems and the development of } \\
\text { solutions }\end{array}$ & $\begin{array}{l}\text { Council politicians define development } \\
\text { processes and issues and work on their } \\
\text { development } \\
\text { Involvement of local politicians in collaborative } \\
\text { spaces to define development strategies }\end{array}$ \\
\hline $\begin{array}{l}\text { The inclusion of different knowledge and joint } \\
\text { problem-solving as a strategy to deal with } \\
\text { complex problems }\end{array}$ & $\begin{array}{l}\text { Involvement of different actors from different } \\
\text { organisations to work on concrete development } \\
\text { issues and define programs (e.g., energy, } \\
\text { employment promotion) } \\
\text { - Involvement of local technical staff in } \\
\text { collaboration spaces } \\
\text { Co-generation between researchers and } \\
\text { policymakers }\end{array}$ \\
\hline $\begin{array}{l}\text { Public administration contributes to improving } \\
\text { stakeholders' problem-solving capacity }\end{array}$ & $\begin{array}{l}\text { - Creation of spaces and strategies for facilitation } \\
\text { capacity-building } \\
\text { - Council supporting and adopting ARTD as a } \\
\text { collective knowing generation strategy }\end{array}$ \\
\hline $\begin{array}{l}\text { Public officials lead intra- and inter- } \\
\text { organizational coordination }\end{array}$ & $\begin{array}{l}\text { - Creation of dialogue spaces between Provincial } \\
\text { Council and county-level territorial actors and } \\
\text { inside the Council }\end{array}$ \\
\hline
\end{tabular}

Source: Authors

As synthetized in Table 2 and further described in the case, the recognition of the complexity that characterises territorial development and the idea that policies and territorial development processes are not only more efficient but also more democratic if they are based on the participation and collaboration of the actors, have promoted collaborative spaces in TDLab between different actors. These collaboration spaces are not only multi-level but also gather politicians and technical staff, breaking the traditional divide between political and technical processes. Their inclusion has been mandatory in order to involve political representatives in defining the goals that affect the territory and technical staff who enact such strategies in practice. A key feature of NPG is precisely to maintain the primacy of politics by engaging elected politicians and public managers in interactive collaborative arenas (Torfing \& Triantafillou, 2013). Council politicians and county politicians have been actively involved in defining and participating in the definition of problems and the strategies to tackle them, and in defining their roles in such endeavours. Moreover, they have all entered and adopted the ARTD approach proposed and developed by researchers as a learning and negotiation approach to generate collective capacities within territorial development.

This has also required that all actors involved (both politicians and technical staff) adopt and/or strengthen their facilitation roles (both intragovernment and extra-government). Intracoordination spaces and mechanisms have also been strengthened in order to tackle together the challenges posed by coordinating the interorganizational spaces and working on issues defined by the actors.

In sum, from a public administration point of view, TDLab has had significant impact on the practices and roles adopted by the Council (and also agencies) in steering such a process:

...the important thing is how things are done: concretely it is necessary to depart from the capacity to work together to 
tackle challenges and problems. The methodology fosters the experimentation with governance models that have multilevel and multi-actor active collaboration within. Moreover, in such process universities inject their knowledge in policy design and implementation processes.

(Statement from the Council representative responsible for TDLab, TDLab Bulletin \#20, August - October 2017)

Hence, fostering territorial development through collaboration has required the adoption of the practices, roles and strategies that NPG proposes for public administration - although in the microenvironment that affects the steering of this process. In TDLab, the practices of collaborative territorial development have merged with the practices of NPG, which makes us consider the fit of the NPG paradigm with cooperative territorial development processes.
On the other hand, the new governance practices in Gipuzkoa that highly respond to the principles of NPG have been developed without any explicit discussion about this paradigm. We consider that this is due to the high connections of NPG and ARTD, the approach through which change has been fostered in TDLab. They both view contexts and policy and territorial development problems as highly complex, where there are multiple conflicting voices involved. Equally, they acknowledge the existence of diverse knowledge and the richness of such knowledge types, which need to be put in favour of collective problem-solving. Derived from this acknowledgement of not only the complexity but also the political nature of the problems and the processes to tackle them, they have an interactive and inclusive view, with a shared understanding of the fact that policy goals and processes are negotiated in interaction processes. These principles also derive from a shared view of collaboration- (and negotiation-) based processes as the means of enhancing collective problemsolving (or collective-knowing) capacity.

Table 2. Similarities of NPG and ARTD

\begin{tabular}{|l|l|l|}
\hline & \multicolumn{1}{|c|}{ NPG } & \multicolumn{1}{|c|}{ ARTD } \\
\hline $\begin{array}{l}\text { View on context and } \\
\text { problems }\end{array}$ & $\begin{array}{l}\text { Context is continuously changing, } \\
\text { problems are complex and policy } \\
\text { goals are developed and negotiated } \\
\text { during interaction processes }\end{array}$ & $\begin{array}{l}\text { Territorial complexity and } \\
\text { conflict are the natural state of } \\
\text { territorial development } \\
\text { processes, and territorial } \\
\text { development is a process of } \\
\text { managing such conflict }\end{array}$ \\
\hline $\begin{array}{l}\text { Knowledge needed for } \\
\text { solving problems }\end{array}$ & $\begin{array}{l}\text { Multiple: political, private, civil } \\
\text { society, etc. }\end{array}$ & $\begin{array}{l}\text { Research knowledge (field and } \\
\text { process knowledge) and } \\
\text { territorial actors' knowledge }\end{array}$ \\
\hline Strategies and principles & $\begin{array}{l}\text { Collaboration, network management, } \\
\text { joint problem-solving, improving } \\
\text { stakeholder problem-solving } \\
\text { capacity... }\end{array}$ & $\begin{array}{l}\text { Co-generation, dialogue, } \\
\text { reflection and action, collective- } \\
\text { knowing generation }\end{array}$ \\
\hline
\end{tabular}

Source: Authors, based on analysis of the case and Hartley (2005), Karlsen \& Larrea (2014), Klijn \& Koppenjan (2016), Torfing \& Triantafillou (2016) and Waldorf et al. (2014).

Thus, with its focus on praxis, dialogue, conflict management and facilitation, ARTD - although not explicitly described in the case due to space issues but detailed in previous works such as Karlsen \& Larrea (2014) - could contribute to public administration and governance scholarship and practice in providing the strategies to foster change towards NPG. As shown in the case, ARTD is a strategy that, by collaborating with policymakers and providing tools to transit from normative ideas to real practices, prevents it from becoming exclusively a theoretical reflection on 
what should be done to transform it into knowing; that is, knowledge in action. As stated by one of the TDLab participants:

TDLab is achieving its aim, is not only a tool for creating knowledge but a project that serves to promote transformation based on an action-research process.

(Statement from a county agency representative, ICT meeting minutes, 15 th September 2016)

\section{Conclusion}

TDLab has illustrated a case in which, through a long-term process, fostering territorial development collaboratively has required and promoted inter-departmental and inter-institutional collaboration, collaboration between political and technical staff, the adoption of strategies to create shared vision, negotiation and joint problemsolving and a transition of the roles of involved politicians and public managers towards a role of orchestrators and facilitators. The changes presented in the case are delimited to a set of actors and practices; and how they connect with, may influence or be influenced by larger institutional and routinized practices has not been analysed. In addition, the case only represents a particular experience in a particular context, and similar experiences could be analysed from this very same perspective. However, based on the case, we could suggest that not only governing society more generally as argued by governance scholars (e.g., Brugué, Canal, \& Paya, 2015; Head \& Alford, 2015; Osborne, 2006) but also steering place-based territorial development may require network-based public organisations. The most recent theoretical developments and policy-led frameworks that are strongly influencing territorial development policymaking at the regional level, such as the smart specialisation strategies, have already noted that governments need distinct capacities to steer this type of more horizontal strategies (Aranguren, Wilson, \& Navarro, 2017; Estensoro \& Larrea, 2016; McCann \& OrtegaArgilés, 2016; Radosevic, Curaj, Gheorghiu,
Andreescu \& Wade, 2017). This article and the experience presented add to those voices by pointing out the relevance of the roles, capacities and structures of governments and public organisations in the promotion of territorial development processes and policies. In our view, governance literature and empirical cases of other fields related to NPG could be a source of learning for our field and for governments that are adopting more horizontal and collaborative regional development and policymaking frameworks.

Moreover, TDLab shows a case in which the changes towards collaboration-based practices in public administration have been fostered through ARTD, an explicit change strategy for territorial development. Similar participatory approaches such as collaborative governance and policymaking and collaborative planning (Healey, 2006; Innes \& Booher, 2003) and other types of co-creation experiences involving citizens (e.g., Bovaird \& Loeffler, 2016) have already been explored as a driver of governance and public innovation. Equally, action research has been widely proven as a change strategy in a wide range of fields through a wide range of empirical cases (Greenwood \& Levin, 2007; Reason \& Bradbury, 2001), including specific public fields such as education and health and more generally regional and territorial governance (e.g., Vasstrom \& Normann, 2014). Adding to this latter line of research and practice in the territorial development field and to our own previous work (Estensoro, 2015; Karlsen \& Larrea, 2014), and based on the strong connections between ARTD and NPG (which due to spaces issues have only been outlined in the article), the complementarities of these two fields would merit further exploration in the view of promoting network-based public organisations that are better suited for cooperative forms of steering territorial development.

\section{Acknowledgments}

The authors wish to acknowledge the support of the Provincial Council of Gipuzkoa through the Etorkizuna Eraikiz programme to the action research processes developed in the Territorial Development Lab. 


\section{References}

Alburquerque, F., Costamagna, P. \& Ferraro, C. (2008). Desarrollo local, descentralización y democracia. Ideas para un cambio. San Martín: UNSAM.

Aranguren, M. J., Wilson, J. R., \& Navarro, M. (2017). From plan to process: Exploring the human element in smart specialisation governance. In P. McCann, F. Van Oort \& J. Goddard (Eds.), The empirical and institutional dimensions of smart specialisation (pp. 165-191). Abingdon: Routledge.

Barca, F., McCann, P. \& Rodríguez-Pose, A. (2012). The case for regional development intervention: Place-based versus place-neutral approaches. Journal of Regional Science, 52(1), 134-152.

Beer, A. \& Clower, T. (2014). Mobilizing leadership in cities and regions. Regional Studies, Regional Science, 1(1), $5-20$.

Bevir, M. (2013). A new governance: Hierarchies, markets, and networks, c. 1979-2010. In M. Osawa \& M. Suginohara (Eds.), ISS Research Series No 55. Reconsidering governance: An interdisciplinary approach (pp. 9-26).Tokyo: Institute of Social Science

Bovaird, T. \& Loeffler, E. (2016). Bringing the resources of citizens into public governance: Innovation through coproduction to improve public services and outcomes. In J. Torfing \& P. Triantafillou (Eds.), Enhancing public innovation by transforming public governance (pp. 160-176). Cambridge, UK: Cambridge University Press.

Bristow, G. (2010). Resilient regions: Re-'place'ing regional competitiveness. Cambridge Journal of Regions, Economy and Society, 3(1), 153-167.

Brugué, Q., Canal, R. \& Paya, P. (2015). ¿Inteligencia administrativa para abordar "problemas malditos"? El caso de las comisiones interdepartamentales. Gestión y Política Pública, XXIV(1), 85-130.

Costamagna, P. \& Larrea, M. (2017). Personas facilitadoras: Su papel en la construcción de capacidades para el desarrollo territorial (Serie Desa). Bilbao: Publicaciones Deusto.

Estensoro, M. (2012). Local networks and socially innovative territories. The case of the Basque Region and Goierri County. Leioa, Spain: University of the Basque Country.

Estensoro, M. (2015). How can social innovation be facilitated? Experiences from an action research process in a local network. Systemic Practice and Action Research, 28(6), 527-545. https://doi.org/10.1007/s11213-0159347-2

Estensoro, M. \& Larrea, M. (2016). Overcoming policy making problems in smart specialization strategies: Engaging subregional governments. European Planning Studies, 24(7), 1319-1335.

Greenwood, D. J. \& Levin, M. (2007). Introduction to action research: Social science for social change (2nd ed..). Thousand Oaks (California): SAGE Publications.

Hartley, J. (2005). Innovation in governance and public services: Past and present. Public Money \& Management, 25(1), 27-34.

Head, B. W. \& Alford, J. (2015). Wicked problems: Implications for public policy and management. Administration \& Society, 47(6), 711-739.

Healey, P. (2006). Collaborative planning. London: Palgrave Macmillan UK.

Innes, J. E. \& Booher, D. E. (2003). Collaborative policymaking: Governance through dialogue. In M. A. Hajer \& H. Wagenaar (Eds.), Deliberative policy analysis: Understanding governance in the network society (pp. 3359). Cambridge: Cambridge University Press.

Karlsen, J. (2010). Regional complexity and the need for engaged governance. Ekonomiaz: Revista Vasca de Economía, 74(2), 36-55.

Karlsen, J. \& Larrea, M. (2014). Territorial development and action research: Innovation through dialogue. Farnhman: Gower.

Klijn, E. H., \& Koppenjan, J. (2016). Governance networks in the public sector. Oxon, UK: Routledge.

Laranja, M. (2012). Network governance of innovation policies: The technological plan in Portugal. Science and Public Policy, 39(5), 655-668.

McCann, P. \& Ortega-Argilés, R. (2016). The early experience of smart specialization implementation in EU cohesion policy. European Planning Studies, 24(8), 1407-1427. https://doi.org/10.1080/09654313.2016.1166177

OECD. (2010). Regional development policies in OECD Countries. Investigaciones regionales. Paris: OECD Publishing.

Orkestra \& Gipuzkoako Foru Aldundia. (2015). Gipuzkoa Sarean. Bidean. Donostia - San Sebastián: Gipuzkoako Foru Aldundia.

Osborne, S. P. (2006). The new public governance? Public Management Review, 8(3), 377-387. 
Pike, A., Rodríguez-Pose, A. \& Tomaney, J. (2007). What kind of local and regional development and for whom? Regional Studies, 41(9), 1253-1269.

Pollitt, C. \& Hupe, P. (2011). Talking about government. The role of magic concepts. Public Management Review, $13(5), 641-658$.

Radosevic, S., Curaj, A., Gheorghiu, R., Andreescu, L. \& Wade, I. (Eds.). (2017). Advances in the theory and practice of smart specialization. London: Academic Press.

Reason, P., \& Bradbury, H. (Eds.). (2001). Handbook of Action Research. Participative Inquiry and Practice. London: Sage Publications.

Sotarauta, M. (2005). Shared leadership and dynamic capabilities in regional development. In I. Sagan \& H. Halkier (Eds.), Regionalism contested: Institution, society and governance (pp. 53-72). Cornwall: Ashgate.

Sotarauta, M. (2009). Power and influence tactics in the promotion of regional development: An empirical analysis of the work of Finnish regional development officers. Geoforum, 40(5), 895-905.

Torfing, J. \& Triantafillou, P. (2013). What's in a name? Grasping new public governance as a politicaladministrative system. International Review of Public Administration, 18(2), 9-25.

Torfing, J. \& Triantafillou, P. (2016). Enhancing public innovation by transforming public governance? In J. Torfing \& P. Triantafillou (Eds.), Enhancing public innovation by transforming public governance (pp. 1-32). Cambridge, UK: Cambridge University Press.

Vasstrom, M. \& Normann, R. (2014). Role transformations in collaborative R \& D-projects as reciprocation between research, practice and policy. International Journal of Action Research, 10(2), 184-211.

Waldorff, S. B., Ebbesen, B. V. \& Kristensen, L. S. (2014). The complexity of governance: Challenges for public sector innovation. In C. K. Ansell \& J. Torfing (Eds.), Public innovation through collaboration and design (pp. 70-88). New York: Routledge. 